\title{
Hospitalization of newborns in Neonatal Unit: the meaning for the mother
}

\author{
Internação do recém-nascido na Unidade Neonatal: significado para a mãe
}

Hospitalización de recién nacidos en Unidad Neonatal: significado para la madre

\begin{abstract}
Bibiana Sales Antunes ${ }^{1}$, Cristiane Cardoso de Paula ${ }^{1}$, Stela Maris de Mello Padoin ${ }^{1}$, Tatiane Correa Trojahn², Andressa Peripolli Rodrigues ${ }^{3}$, Caroline Sissy Tronco ${ }^{4}$
\end{abstract}

This study aimed to understanding the meaning of hospitalization of the newborn child in the Neonatal Intensive Care Unit. It is a descriptive research of a qualitative approach. The interviews were conducted from December 2010 to April 2011, with seven mothers of newborns admitted to teaching hospital in the State of Rio Grande do Sul, Brazil. The content analysis resulted in three categories: the admission in the Neonatal Intensive Care Unit generates concerns and difficulties; need for professional care and use of technologies; in routine between home and the hospital the mother feels tired, sad and insecure. So, we must consider that there are characteristics of each mother in adapting to the Neonatal Intensive Care Unit environment. Attentive, responsive and individualized listening enable the professional care meets the needs of care to mothers in their uniqueness.

Descriptors: Intensive Care Units, Neonatal; Infant, Newborn; Mothers; Breast Feeding; Nursing.

Objetivou-se compreender o significado da internação do filho recém-nascido em Unidade de Terapia Intensiva Neonatal. Pesquisa descritiva, de abordagem qualitativa. As entrevistas foram realizadas de dezembro/2010 a abril/2011, com sete mães de recém-nascidos internados em hospital de ensino no interior do Estado do Rio Grande do Sul, Brasil. Análise de conteúdo resultou em três categorias: internação na Unidade de Terapia Intensiva Neonatal gera preocupações e dificuldades; necessidade de atendimento profissional e uso de tecnologias; rotina entre a casa e o hospital, a mãe se sente cansada, triste e insegura. Assim, deve-se considerar que existem particularidades de cada mãe na adaptação ao ambiente da Unidade de Terapia Intensiva Neonatal. A escuta atenta, sensível e individualizada possibilitará que o profissional atenda às necessidades de cuidado às mães em sua singularidade.

Descritores: Unidades de Terapia Intensiva Neonatal; Recém-Nascido; Mães; Aleitamento Materno; Enfermagem.

El objetivo fue comprender el significado de la hospitalización del recién nacido en Unidad de Cuidados Intensivos Neonatales. Investigación descriptiva, con enfoque cualitativo. Las entrevistas se realizaron entre diciembre de 2010 y abril de 2011, con siete madres de recién nacidos ingresados en un hospital universitario del Rio Grande do Sul, Brasil. El análisis de contenido resultaron en tres categorías: la hospitalización en Unidad de Cuidados Intensivos Neonatales genera preocupaciones y dificultades; la necesidad de atención profesional y el uso de tecnologías; en la rutina entre el hogar y el hospital, la madre se siente cansada, triste e insegura. Por lo tanto, se debe tener en cuenta que hay características de cada madre para adaptarse al medio ambiente de la Unidad de Cuidados Intensivos Neonatales. La escucha atenta, sensible e individualizada permite la atención del profesional a las necesidades de cuidados a las madres en su singularidad.

Descriptores: Unidades de Cuidado Intensivo Neonatal; Recién Nacido; Madres; Lactancia Materna; Enfermería.

\footnotetext{
${ }^{1}$ Universidade Federal de Santa Maria. Santa Maria, RS, Brazil.

${ }^{2}$ Hospital Universitário de Santa Maria. Santa Maria, RS, Brazil.

${ }^{3}$ Universidade Federal do Ceará. Fortaleza, CE, Brazil.

${ }^{4}$ Universidade Federal do Rio Grande do Sul. Porto Alegre, RS, Brazil.

Corresponding author: Bibiana Sales Antunes

Av. Roraima no 1000, Cidade Universitária, prédio 26, sala 1336. Bairro Camobi. CEP: 97105-900 - Santa Maria, RS, Brazil. E-mail: bibianaantunes@hotmail.com
} 


\section{Introduction}

Neonatal mortality accounts for approximately $70 \%$ of deaths in the first year of life. In Brazil, in the last ten years there has been a significant increase in the number of survivors children in the early years of life, since the infant mortality rate in 2000 was 27.4 / thousand live births in 2008 and was reduced to 17.6/ thousand live births ${ }^{(1)}$.

It is noteworthy that premature birth is the most common cause of neonatal morbidity and is associated with $75 \%$ mortality. These newborns, mostly, are critically ill, highly vulnerable who need special and continuous care, requiring hospitalization in the Neonatal Intensive Care Unit ${ }^{(2)}$.

The Neonatal Intensive Care Units have undergone several changes due to new technologies that influenced the increased survival of the newborn. This technology investment also involves the team of health professionals, who need to have a specialized scientific knowledge, technical skill and expertise to carefully evaluate the particularities of these newborns ${ }^{(3)}$.

Thus, the care provided to the newborn should include activities aiming to individualize the assistance provided to baby and its family and not only to restore the anatomical and physiological body, minimizing potential damage that can lead to hospitalization $^{(3-4)}$. In this sense, many neonatal services are concerned about becoming cosy and less impersonal environments, not only in its physical space, but also the team behaviour, combining technological resources to the humanized care ${ }^{(5)}$.

The admission of the newborn can trigger fear, anguish, anxiety, impotence in families, due to the distance from the baby, the rules and routines of the Intensive Care Unit, the vagaries of everyday life and the possibility of death of newborn. On one hand hospitalization in the Neonatal Unit can generate negative feelings in parents ${ }^{(6)}$, on the other the host and their participation during hospitalization can minimize the effects posed by hospitalization, and contribute to the treatment and recovery of child ${ }^{(4-5)}$.
Thus, one of the goals of care in Neonatal Intensive Care Units is to intensify the bond between the family and the baby, and for this it is necessary that attention to parents is included in the priorities of neonatology services ${ }^{(6)}$. So, it is necessary for the health team encourages daily maternal care such as feeding, bathing, changing diapers, etc ${ }^{(7)}$.

It is noticed that the Neonatal Intensive Care Unit is an unfamiliar environment, surrounded by high technology, and that, besides the care for the newborn; attention should be paid to the family that in this scenario, is weakened by the admission of the baby. Thus, it was pointed out as the research question: How does the mother understand the hospitalization of newborns in the Neonatal Intensive Care Unit?

This study aimed to understand the meaning of hospitalization of the newborn child in the Neonatal Intensive Care Unit for mothers. Such study is justified due to the challenges experienced by mothers during hospitalization of the newborn, which may promote comprehensive and individualized care to the mother, so she can deal the admission of her child.

\section{Method}

This is a descriptive study, developed through a qualitative approach, which works with a plethora of meanings, reasons, aspirations, beliefs, values and attitudes ${ }^{(8-9)}$. The present study consists of a subproject developed from the analysis of the database of interviews of matrical project called "The daily life of being-mom-of-a-newborn on the maintenance of lactation in the Neonatal Intensive Care Unit: possibilities for nursing".

Open interviews were conducted from December 2010 to April 2011 in a private room within the Neonatal Intensive Care Unit from a school-hospital of reference in service of medium and high complexity for the mid-west region of Rio Grande do Sul, Brazil. The following question was used: how is it being to milk to feed her son? The testimonies of mothers las- 
ted 15-40 minutes and were recorded by consent, and the transcript of the interviews was as the original speech, being pointed silences and bodily expressions observed during the meeting.

Interviews with seven mothers who had their newborns hospitalized in the Neonatal Intensive Care Unit and who were in maintenance of lactation due to the baby's clinical condition were performed; mothers who stopped breastfeeding were excluded. The number of interviews followed the criterion of saturation of information, considering the repetition and uniformity of responses ${ }^{(10)}$.

We used content analysis, in three steps: pre-analysis, material exploration and interpretation of results ${ }^{(11)}$. In the pre-analysis the formation of hypotheses and objectives was developed to reference indices and the development of indicators (frequency of appearance) and the preparation of the material. In the exploration of material, clippings in record and context units were performed. Finally, the interpretation of the results allowed the contents that answered the research question were discussed within the literature produced on the subject, pointing out similarities and differences.

The study was approved by the Committee on Ethics and Research of the Federal University of Santa Maria (CAAE: 0294.0.243.000-10). To maintain anonymity, the interviews were coded with the letter $\mathrm{M}$ for mother, then the numbers 1-7.

\section{Results}

According to the characterization of mothers, 5 (five) reported being married and 5 (five) had completed high school or are ongoing. Some of them (4) had two children and the age ranged from 21 to 36 years.

Content analysis of the interviews revealed three categories: the admission to the Neonatal Intensive Care Unit generates concerns and difficulties; need for professional care and use of technologies in the Neonatal Intensive Care Unit and in this routine between home and the hospital the mother feels tired, sad and insecure. The themes of the study are presented below.

\section{The admission to the Neonatal Intensive Care Unit generates concerns and difficulties}

In this category, the mothers expressed that hospitalization in the Neonatal Intensive Care Unit generates concerns and difficulties because mothers think this a frightening environment. During pregnancy the woman projects the caring to her son soon after giving birth to, there is a family preparation for baby's arrival. However, finding the prematurity of her baby and sees it being taken to the Neonatal Intensive Care Unit, worries, anxieties and fears are manifested. So we get quite worried. I was quite terrified to see her there in the early days (M1). It is the situation I am not resigned (M2). But seeing it up here was horrible [crying], because when I came it was with tube in the nose, mouth, everything is pretty scary in here (M4). Sadly, I wanted her to generate, there is no explanation (M5). When they told me "Your son goes to phototherapy ..." I was terrified they said "Your son goes to the Intensive Care Unit", you know? So at first, horrible, because for me until then I did not know why. So I was terrified, the word Intensive Care Unit is, right, for God's sake, you are dying (M7).

Regarding the difficulties, the mothers reported that hospitalization of the newborn is difficult because they are not prepared to see their children in health clinics condition in an unfamiliar environment for them. As the days go by, the faith becomes an emotional support for them, serving as a source of healing and survival of newborn. The first days were terrible, difficult; I went out pretty badly to see her in the incubator. We were not prepared for all that in there, to see her there. So I was pretty bad in the first days (M1). There are moments that we feel some agony and you have to cry, so I am almost every day without knowing what will happen (M2). It is difficult to sleep here in the hospital, everything is unpleasant, uncomfortable (M3). When they told me he was coming here, I thought: Oh, again!, we think: Again, my God!, but is giving to take; is difficult, but it passes. God knows what to make, no use; it's alright, thank God, all is settling (M4). It's tricky, bah! It is not easy; I have a lot of faith, I pray that she will come out very soon; I have faith in God, 
if God wants, nothing is impossible (M5). I am just praying now (M6). For me it is hard and difficult for me so I stayed with him two days, then he went up, it's very complicated. I am a first time mother, very complicated, very difficult (M7).

The unknown environment, lack of information and the instability of the newborn can also cause fear the loss of the baby, which is expressed by mothers when they live with the uncertainty of life and imminent risk of death. This happens due to the instability of the newborns health status, resulting in distress, even though the mothers try to be prepared for any situation. Each day is one thing. You think they will discharge and they do not (M1). Knowing the answer makes you fear; my God, what is [child's name] doing here, a big baby, doing treatment, I know he needs this treatment here, but distresses me (M2). We have ups and downs, anything can happen, you have to be prepared for everything. You cannot say it is okay, almost okay (M5).

\section{Need for professional care and use of technologies in the Neonatal Intensive Care Unit}

Regarding the understanding that the child needs professional care, mothers recognized that care was performed in a caring and thoughtful way with the newborns, which safely conveyed to mothers, besides the reception and care of the nursing staff in moments of weakness, mainly through dialogue. But the rest is all quiet. The nurses are very attentive to her (M1). Nurses are very affectionate with me, answer my questions, the family ... what I am doing, here is the nurses, you know, talk to us; they talk, explain me, soothe me; help the time pass, you know, and make me a bit concerned of the situation, and so they all talk, if you are kind of down, they ask: "are you sad today, Mom, why?" (M2). The girls are very thoughtful; sometimes when you're just wanting to drop, the girls come and, not "No, Mom, calm down, it get better, it passes ..." Then we get a joy, but if not (M4). Nurses are very patient, they talk and we make a friendship with the nurses. Anything we ask they have an answer to give us about the babies. If they do not have, they try to find the answer in time (M6). Then I talked, they talked to me, calmed me, it is in their hands, we see that it is very well treated (M7).

In addition, mothers understand that the child requires the use of technology for its survival and/or treatment in the Neonatal Intensive Care Unit. They recognize it is a place full of machines and common procedures for the team, but unknown to them and begin to live with sound and light signal equipment. There are the best resources here (M2). Every time one of those machines beeps, we take a fright, whistling, we fear (M4). Sadly, at the same time happy because she is in the middle of the action; and all the resources are giving her what she needs (M5). But here we are in the resource (M7).

\section{In this routine between home and the hospital the mother feels tired, sad and insecure}

In this category, mothers recognize that the admission demand a routine between home and the hospital, and the mother feels tired, sad and insecure. The daily life of the mother suddenly changes after childbirth, being necessary to adapt the house and family tasks to the routine visits to the hospitalized child. As a mother, she feels the need to visit often her son. Sometimes we feel tired from the routine of coming and going (M1). Because my routine at home is very quiet. Here is very busy, there is too much movement for me. That's it, you know, it's all [sigh] very busy, very different (M2). So I prefer to go home, I am more relaxed, more peaceful. Hence I prefer coming every day, so I'm staying, uh, I become more complete, I think (M3). I am too tired of going back and forth, back and forth (M4). The day to day is a rush (M5). Alas, it is a well run (M6).

The routine of going and coming back to live with her child generates physical and psychological fatigue for the mom. However, as M1 reports, the mother is considered to be a tireless. Mother has no tiredness (M1). Ah, it's tiring (M3). Tired, so tired (M4).

Mothers plan to return to their homes with their children, but the admission separates mother and child. They reported the removal as an experience of suffering and insecurity. I will only rest when she is home, we feel more peaceful (M1). Obviously I want to have taken him home now, but that's okay, it's not the end of the world (M3). When you get pregnant, you plan to have your baby with you. Then suddenly you do not have your baby with you, because you leave the hospital alone, without the baby in her arms is horrible. I wanted to be at home [crying] 
with my children with him, it is bad we're not in our house and not in my mother's house (M4). No mother wants to gain the child and leave in the hospital, she wants to take home (M5). I stay at home in the week now, because I work. We do not want, I do not want to go back, even in high school, I left a bit aside these things, to take care of the house a little bit, because then I can stay here all the time is not that scary, but it is difficult for us to see little child and do not stay there (M6). I leave it here, it's horrible, it's very sad to have to leave our baby here. It's hard to leave the baby here and go home (M7).

Having a child in the Neonatal Intensive Care Unit generates disorders in the mothers' daily life that need to live with the newborn and their other children; they must share the presence and attention among the children. During hospitalization, they prioritize the hospitalized newborn because of the severity of the condition and fear of loss. Sometimes this removal causes them a feeling they are abandoning their other children. Sometimes you cannot listen to one, pay attention to the other, you frightens you a little bit (M1). I want to be close to my other son too, I miss him, to hug and to kiss, I know that now the priority is [child's name] (M2). I have others too, so we get up for the children we already have (M4).

\section{Discussion}

The birth of a baby in the family is one of the most expected moments, which causes parents the feeling of extreme happiness. However, when the risk newborn needs to be admitted to a Neonatal Intensive Care Unit, the parents face a stressful and challenging experience which leads to sudden changes in the family setting. During this period of hospitalization, the mother suddenly becomes the companion of a child, without being prepared for this situation ${ }^{(12)}$.

The shock caused by the hospitalization of a baby in the Neonatal Intensive Care Unit can be understood when we see parents being confronted with a stressful and unfamiliar environment, with a feeling of powerlessness to take care of your child who is at risk for life. Prolonged hospitalization of infants and the limitation of the environment can lead to stress in the mother and the other family, which may impair the bond between the mother-child ${ }^{(13)}$.

The admission of the newborn in the Neonatal Intensive Care Unit cares for the welfare of the child, however, is an impersonal and even fearful environment for those who are not adapted to their routines. This environment is filled with bright lights and constant noise, temperature changes, switching the sleep cycle, since various evaluations and procedures are required, resulting often, discomfort and pain ${ }^{(4)}$.

Given the fact that the mothers not to feel prepared to face such a situation, we emphasize the importance of staff involvement in assisting the binomial mother-son, emphasizing the need to humanize this care, facilitating interaction between professional sta$\mathrm{ff} /$ newborn/mother. In this sense, care provides recovery, growth and development of the newborn, minimizing the harmful effects caused by hospitalization, making the mother an active element in the hospitalization process, contributing to the quality of survival of the child ${ }^{(4)}$.

Moreover, faith can generates comfort and security for coping with hospitalization in the Neonatal Intensive Care Unit. Still, eases anxiety and suffering on the situation of illness of the child ${ }^{(14-16)}$.

Due to the advance of medicine in general, and specifically in neonatology, new technologies are incorporated in neonatal care. Often, this can turn the baby into an object of care and mothers become only observers. Therefore, there is need for that, parallel to technological development, is promoted humanized care, in which the newborn is recognized as a subject with individuals, maintaining relationships with your social scene ${ }^{(17)}$.

In this sense, there is also need of the healthcare team to know the daily life, culture, concerns and fears of the mothers so that there is an effective and individualized care, since the family is under the control of a hospital structure and the dependence of professionals ${ }^{(18-19)}$.

The team instrumentalization can also occur from the use of some everyday practices in Neonatal Intensive Care Unit, with the aim of developing com- 
munication and team working skills. For this, there is need of the professionals predisposition involved to value family, especially the mother, as the focus of care. Thus, a scenario of interaction of different people, concepts, values and cultures in which each player is different and is recognized in the other, from dynamics that enable talk, listen, feel, reflect and learn to think can be promoted ${ }^{(7)}$.

The model based on the mechanistic logic, which aims at the maintenance and recovery of the baby, is replaced by a model that emphasizes full, humanized and preventive care, grounded in the health/disease/care. Therefore, to be a humanized care in the Neonatal Intensive Care Unit, space dominated by technological advancements, it requires the incorporation of care to mothers in neonatal care ${ }^{(20)}$.

The admission of the newborn in the Neonatal Intensive Care Unit generates the breakdown of family routine, with the disruption to daily life, the removal of other family members, changing household tasks, the need for involvement of others to support mainly the other children who are experiencing the consequences of the removal of the mother ${ }^{(21)}$.

The length of admission results in mixed feelings, where, at the same time, the family person wants to be with the baby, but finds himself divided between his and the family's needs longing for the return home to resume a familiar routine. This causes the mother holds an expectation with respect to the son post-discharge from Neonatal Intensive Care Unit ${ }^{(21-22)}$.

The hospitalized child becomes priority and mothers distance themselves from their duties of wife, partner, employee, daughter and mother of other children to become the mother of a newborn who needs hospital care, setting up a difficult situation and distressing for them. They begin to live with a new daily life and face with the need to confront and adapt to the new condition ${ }^{(13)}$.

During hospitalization in Neonatal Intensive Care Unit, in the experience of the routine of coming and going to the hospital and with high expectation, parents experience uncertainty about the survival of the newborn and the fear of death, which cause daily suffering ${ }^{(22-24)}$. Thus, the experience of child hospitalization affects the lives of all around him, it is essential that the care provided in the Neonatal Intensive Care Unit minimize the consequences that can cause hospitalization.

\section{Conclusion}

The present study showed that mothers understand that admission to the Neonatal Intensive Care Unit generates concerns and difficulties, being necessary professional care and use of technologies for the recovery of newborns. As a consequence of hospitalization, routine between home and the hospital generates tiredness, sadness and insecurity, and the newborn becomes priority to maternal care compared to other children.

In such situations, the importance of developing professional communication skills and effective listening is highlighted so that care is performed in a humane manner. It must be considered that there is a particularity of adaptation of every mother and an attentive, responsive and individualized listening will enable health professionals an effective and respectful performance, considering the needs of care to mothers as unique beings.

It is understood that it is essential to provide professionals so that they can realize the humanized care by knowing and understanding the experiences of mothers of hospitalized newborns in the Neonatal Intensive Care Unit. The careful, sensitive and individualized listening enable the professional meets the needs of care to mothers in their uniqueness.

As limitation we point the use only of the mothers as subjects, expansion to parents or other family members accompanying the admission of the newborn in the Neonatal Intensive Care Unit is required. 


\section{Collaboration}

Tronco CS contributed to the design, collection and organization of the study, Antunes BS and Trojahn TC to the data analysis and interpretation and the article composition. Paula CC, Padoin SMM and Rodrigues AP contributed to the article composition, critical revisions of the study and its final approval to be published.

\section{References}

1. Ministério da Saúde (BR). Departamento de Informática do SUS - DATASUS. Indicadores de mortalidade. Taxa de mortalidade infantil [Internet]. 2012 [citado 2014 fev. 17]. Disponível em: http://tabnet.datasus.gov.br/cgi/idb2010/ c01b.htm

2. Salgel AKM, Vieira AVC, Aguiar AKA, Lobo SF, Xavier RM, Zatta LT, et al. Fatores maternos e neonatais associados à prematuridade. Rev Eletr Enf [periódico na Internet]. 2009 [citado 2014 fev. 17]; 11(3):642-6. Disponível em: http://www.fen. ufg.br/revista/v11/n3/pdf/v11n3a23.pdf

3. Costa R, Padilha MI, Monticelli M. Production of knowledge about the care given to newborns in neonatal IC: contribution of Brazilian nursing. Rev Esc Enferm USP. 2010; 44(1):194-9.

4. Braga PP, Sena RR. Cuidado e diálogo: as interações e a integralidade no cotidiano da assistência neonatal. Rev Rene. 2010; 11(n. esp.):142-9.

5. Soares LO, Santos RF, Gasparino RC. Necessidades de familiares de pacientes internados em unidade de terapia intensiva neonatal. Texto Contexto Enferm. 2010; 19(4):644-50.

6. Martins L, Oliveira EA. Percepções da mãe diante dos cuidados de saúde oferecidos ao binômio mãe/recém-nascido na internação neonatal. Com Ciênc Saúde. 2010; 21(2):107-16.

7. Araújo BBM, Rodrigues BMRD. Mothers' experiences and perspectives regarding their premature infant's stay at the Neonatal Intensive Care Unit. Rev Esc Enferm USP. 2010; 44(4):86572.
8. Minayo MCS. O desafio do conhecimento: pesquisa qualitativa em saúde. $12^{\underline{a}}$ ed. São Paulo: Hucitec; 2010.

9. Paula CC, Cabral IE, Souza IEO, Padoin SMM. Analytical movement - Heideggerian hermeneutics: methodological possibility for nursing research. Acta Paul Enferm. 2012; 25(6):984-9.

10. Fontanella BJB, J Ricas, Luchesi BM, Saidel MGB, Ricas J, Turato ER, et al. Amostragem em pesquisas qualitativas: proposta de procedimentos para constatar saturação teórica. Cad Saúde Pública. 2011; 27(2):389-94.

11. Bardin L. Análise de conteúdo. Lisboa: Edições 70; 2011.

12. Santana EFM, Madeira LM. A mãe acompanhante na unidade de terapia intensiva neonatal: desafios para a equipe assistencial. Rev Enferm Cent-Oeste Min. 2013; 3(1):475-87.

13. Schmidt KT, Sassá AH, Veronez M, Higarashi IH, Marcon SS. A primeira visita ao filho internado na unidade de terapia intensiva neonatal: percepção dos pais. Esc Anna Nery. 2012; 16(1):73-81.

14. Santos LM, Silva CLS, Santana RCB, Santos VEP, Franco BC. Rede e apoio social de pais de prematuros hospitalizados na unidade de terapia intensiva neonatal. Rev Pesq Cuid Fundam [periódico na Internet]. 2012 [citado 2014 mar. 14]; 4(4):2789-96. Disponível em: http://www. seer.unirio.br/index.php/cuidadofundamental/ article/view/1807/pdf_617

15. Lima FA, Amazonas MCLA, Menezes WN. Estrategias de enfrentamiento (Coping) de hijos que tienen la madre o el padre internado en una Unidad de Terapia Intensiva (UTI). Divers Perspect Psicol. 2012; 8(1):151-64.

16. Véras RM, Vieira JMF, Morais FRR. A maternidade prematura: o suporte emocional através da fé e religiosidade. Psicol Estud. 2010; 15(2):325-32.

17. Tronco CS, Paula CC, Padoin SMM, Langendorf TF. Análise da produção científica acerca da atenção ao recém-nascido de baixo peso em UTI. Rev Gaúcha Enferm. 2010; 31(3):575-83. 
18. Pinheiro EM, Balbino FS, Balieiro MMFG, Domenico EBLD, Avena MJ. Percepções da família do recémnascido hospitalizado sobre a comunicação de más notícias. Rev Gaúcha Enferm. 2009; 30(1):7784.

19. Manthey M. The 40th anniversary of primary nursing: Setting the record straight. Creative Nurs. 2009; 15(1):36-8.

20. Costa R, Padilha MI. A Unidade de Terapia Intensiva Neonatal possibilitando novas práticas no cuidado ao recém-nascido. Rev Gaúcha Enferm. 2011; 32(2):248-55.

21. Lamy ZC, Morsch DS, Deslandes SF, Fernandes RT, Rocha LJLF, Lamy Filho F, et al. Construção do papel materno a partir da vivência de internação em UTI neonatal em dois modelos assistenciais. Rev Pesq Saúde. 2011; 12(1):14-21.
22. Santos AA, Pedrosa IL, Vasconcelos JMB, Arruda AC. A internação de um recém-nascido na unidade de terapia intensiva neonatal: desvelando sentimentos e expectativas dos pais. Rev Enferm UFPE on line [periódico na Internet]. 2011 [citado 2014 mar. 17]; 5(6):1492-500. Disponível em: http://www.revista.ufpe.br/revistaenfermagem/ index.php/revista/article/view/16.

23. Neves ET, Cabral IE. Empoderamento da mulher cuidadora de crianças com necessidades especiais de saúde. Texto Contexto Enferm. 2008; 17(3):552-60.

24. Soares LG, Lima VF, Soares LG, Baratieri T, Botti ML. Nursing in neonatal intensive care: the look of the families. Rev Rene. 2014; 15(1):12-21. 